William \& Mary Law School

William \& Mary Law School Scholarship Repository

Faculty Publications

Faculty and Deans

$12-2017$

\title{
Were the 1982 Merger Guidelines Old News?
}

Alan J. Meese

William \& Mary Law School, ajmees@wm.edu

Sarah L. Stafford

William \& Mary Law School, slstaf@wm.edu

Follow this and additional works at: https://scholarship.law.wm.edu/facpubs

Part of the Antitrust and Trade Regulation Commons, Business Organizations Law Commons, and the Law and Economics Commons

\section{Repository Citation}

Meese, Alan J. and Stafford, Sarah L., "Were the 1982 Merger Guidelines Old News?" (2017). Faculty

Publications. 2036.

https://scholarship.law.wm.edu/facpubs/2036

Copyright c 2017 by the authors. This article is brought to you by the William \& Mary Law School Scholarship Repository.

https://scholarship.law.wm.edu/facpubs 


\title{
WERE THE 1982 MERGER GUIDELINES OLD NEWS?
}

\author{
Alan F. Meese Ev Sarah L. Stafford $^{\dagger}$
}

\begin{abstract}
This paper examines the impact of the 1982 Department of Justice Merger Guidelines on the stock market prices of publicly traded firms in the United States. We argue that those Guidelines were perceived by the market as a real change in enforcement policy that would result in substantial deregulation of mergers throughout the economy. We conduct an event study of S\&P 500 firms to test this hypothesis and find evidence of a significant positive effect on the stock prices of firms in moderately concentrated industries subject to antitrust regulation, the firms for which the 1982 Guidelines articulate a substantially less intrusive enforcement policy. However, the announcement does not have any significant effect on firms in less concentrated industries or those that are highly concentrated. These results are robust to a number of different sensitivity analyses and thus we conclude that market actors believed the 1982 Guidelines contained new information.
\end{abstract}

$\mathscr{f E L}: \mathrm{K} 21 ; \mathrm{L} 41 ; \mathrm{L} 44$

\section{INTRODUCTION}

The Clayton Antitrust Act, enacted in 1914, bans mergers that may "substantially lessen competition" and empowers the Department of Justice (Department) to challenge those transactions it believes would violate this standard. The Department's policy governing whether to challenge proposed mergers, that is, its merger enforcement policy, is an important part of the $U$. S.'s overall antitrust regime. This policy not only affects which mergers will be allowed, it also affects the costs of merging because, even if unsuccessful, any challenge will impose significant costs on merging parties. Ultimately, the Department's merger enforcement policy serves as a form of regulation

\footnotetext{
* Ball Professor of Law, William and Mary Law School and Co-Director, William and Mary Center for the Study of Law and Markets. Email: ajmees@wm.edu.

t Verkuil Professor of Public Policy, Economics and Law, College of William and Mary. Email: slstaf@wm.edu. The authors would like to thank James Hamilton, Keith Hylton, Katherine Litvak, and Daniel Sokol, participants in the William and Mary Law School 2015 Summer Scholarship Workshop and several anonymous referees for helpful comments. The authors received a William and Mary Faculty Interdisciplinary Initiatives Grant funded by the Andrew W. Mellon Foundation for the Humanities in support of this project.
} 
with the result that changes to that policy can affect the profitability of firms subject to the Clayton Act.

Not surprisingly, firms and the lawyers who represent them are keenly interested in the Department's merger enforcement policy. The Department can communicate enforcement policy to market actors in various ways. Official speeches, decisions to bring or drop litigation, congressional testimony and positions taken in amicus briefs all send signals (sometimes conflicting or unclear) about the content of the Department's enforcement policy. In 1968, the Department developed another communication tool, the so-called Merger Guidelines. Although not legally binding on the Department or private parties, the 1968 Merger Guidelines articulated a fully-specified methodology for analyzing mergers under the Clayton Act, which governs nearly all significant mergers in the American economy. They thus provided important regulatory guidance to lawyers and the business community by articulating the standards the Department would apply when deciding whether to challenge a proposed transaction.

By modern standards, the 1968 Guidelines were very intrusive, condemning horizontal mergers between firms with modest shares of unconcentrated markets. Although developments in judicial doctrine and economic theory soon undermined the legal and economic premises driving such extensive regulation, the 1968 Guidelines remained on the books as official Department policy through the late 1970s and beyond, even as the Department reportedly softened its actual enforcement posture. Finally, in 1982, the Reagan Justice Department released a set of revised Merger Guidelines that better aligned the Department's enforcement policy with case law and the teachings of economic theory. Like the 1968 Guidelines they replaced, the 1982 Guidelines articulated a comprehensive methodology for assessing proposed mergers, thereby informing market actors what types of transactions the Department would and would not challenge in the future.

On their face, the 1982 Guidelines were significantly less intrusive than the 1968 Guidelines and thus appeared to constitute significant deregulation. For instance, the new guidelines raised the concentration thresholds necessary to trigger a challenge, thereby creating de facto safe harbors for numerous transactions the 1968 Guidelines would have condemned outright. Moreover, and unlike the 1968 Guidelines, the new Guidelines required the Department to consider various factors in addition to concentration, such as ease of entry, before challenging a transaction. Thus, the new Guidelines signaled that the Department would decline to challenge some transactions that exceeded the Guidelines' new and higher concentration thresholds.

Like their predecessors, the 1982 Guidelines were a nonbinding statement of "present enforcement policy." Moreover, most commentators agree that enforcement policy had evolved significantly in a less interventionist direction even before the 1982 announcement. Indeed, well before the 1982 announcement, the principal author of the 1982 Guidelines, Assistant Attorney General 
William Baxter, had expressly declared that the 1968 Guidelines were no longer accurate reflections of the Department's enforcement policy. The Department had even gone so far as to dismiss a merger challenge brought by the Carter Administration because the resulting market shares and concentration, although higher than the thresholds requiring a challenge under the 1968 Guidelines, did not warrant an inference of post-merger anticompetitive effects. "These developments provided a form of regulatory guidance to market actors who presumably adjusted their conduct, including the propensity to merge and identity of merger partners, accordingly.

Did the new 1982 Guidelines have any meaningful effect? Our review of the literature suggests two quite different answers to this question, each implying or invoking a different understanding of the nature of enforcement policy change. Each answer also has markedly different implications for our understanding of the effectiveness of enforcement Guidelines as a regulatory tool. One account contends that merger enforcement policy evolved continuously between 1968 and mid-1982, as officials incrementally, repeatedly, and publically revised their enforcement posture toward horizontal mergers in response to case law developments, evolution in economic theory, and experience gained from investigations. As a result, the 1982 Guidelines would have signaled no material change in actual enforcement policy but instead simply enshrined changes in enforcement policy that had already occurred earlier. Under this view, the 1982 Guidelines were a restatement, as it were, of what potentially affected parties presumably already knew about the Department's enforcement policy and should have had no effect on the market.

The other account argues that enforcement policy can sometimes change abruptly and in ways not entirely anticipated. For example, two scholars assert that "firms find it difficult to anticipate such changes in merger policy, as they represent politically-driven exogenous shocks to merger policy." 2 Proponents of this view assert that the 1982 Guidelines represented a real change in merger enforcement and had a substantial effect on market actors. In fact, many have attributed part of the 1980 s merger wave to the relaxed enforcement policy memorialized in the 1982 Guidelines. ${ }^{3}$ According to this account, the new 1982 Guidelines functioned as an economy-wide deregulatory shock, not anticipated by market actors, that removed perceived barriers to mergers in various industries and thus had a real effect on the market.

Did the 1982 Guidelines simply describe a regulatory regime already in place, thereby reiterating what the Department had already signaled to the

${ }^{1}$ See U.S. Drops Trust Suits Against Mack, Two Others, New York Times, July 9, 1981, at D1.

2 Joseph A. Clougherty \& Jo Seldeslachts, The Deterrence Effects of U.S. Merger Policy Instruments, 29 J. L., ECON. \& ORG. 1114, 1131 (2013).

3 See, e.g., William G. Shepherd, Public Policies toward Business, 211-12, 221-22, 226 (1991); Linda Brewster Stearns \& Kenneth D. Allan, Economic Behavior in Institutional Environments: The Corporate Merger Wave of the 1980s, 61 AM. Sociol. REv. 699, 703-6 (1996). 
market via speeches, testimony, briefs and enforcement actions? Or, instead, did they convey new and important information to market actors and signal economy-wide relaxation of antimerger enforcement and thus significant deregulation? This article seeks to answer those questions by examining the behavior of those individuals with the most robust incentives to ascertain the impact of the 1982 announcement, namely, investors in firms potentially affected by the change. To determine investors' reactions, we employ the event study methodology developed by financial economists. Such studies harness the informational efficiencies of securities markets to measure the impact, if any, of unanticipated regulatory change on the value of firms whose securities are traded in public markets. As we argue later in this paper, the announcement of the 1982 Guidelines is well-suited to this method.

If, as some have suggested, the 1982 Guidelines simply reiterated positions the Department had already taken, one would expect little or no reaction from investors to the 1982 announcement. If, on the other hand, the new Guidelines signaled unanticipated change in merger enforcement policy, we would expect securities prices of affected firms to react accordingly. Our analysis finds that the 1982 announcement in fact had a positive impact on the share prices of firms likely affected by such change, namely, firms in moderately concentrated industries not exempt from the Clayton Act. This group corresponds roughly to the group of firms with respect to which the new Guidelines announced a less intrusive enforcement policy. Investors in those firms apparently believed that the 1982 Guidelines signaled a more relaxed enforcement policy going forward than had previous statements, testimony and litigation positions.

The remainder of this article is organized as follows: Section II provides background on the evolution of merger enforcement policy from the 1950s through the development of the 1982 Guidelines. Section III identifies alternate hypotheses about the impact of the 1982 Guidelines. Section IV describes the method we propose to test these hypotheses and reports the results of our analysis. Section $\mathrm{V}$ interprets our results and describes some additional robustness tests that we conduct. Section VI concludes.

\section{BACKGROUND ON MERGER ENFORCEMENT POLICY}

Merger enforcement policy evolves over time in response to changes in economic theory and case law. Market actors presumably monitor such evolution and adjust their propensity to merge and the identity of merger partners accordingly. This section details this evolution in enforcement policy, including the policy contained in the 1968 Merger Guidelines and pursued in the 1970 s, subsequent changes in the case law and economic theory, indications by the Department that the 1968 Guidelines were no long accurate statements of enforcement policy, and the significantly relaxed enforcement policy contained in the 1982 Merger Guidelines. 


\section{A. Post-1950 Merger Enforcement Policy and the 1968 Guidelines}

Beginning in the mid-1950s, the Department challenged numerous transactions in markets that would appear quite competitive today. In United States v. Von's Grocery, ${ }^{4}$ for instance, the Department attacked, and the Supreme Court condemned, a merger creating a firm with a 7.5 percent share of a market with over 3,700 firms and a Herfindahl-Hirschman Index (HHI) below 500, even though 173 firms had entered the market in the preceding decade. ${ }^{5}$ The Department claimed that the merger epitomized a trend toward oligopoly, although the Court concluded that it exemplified a trend toward fewer independent firms in the relevant market, ignoring any potential efficiencies and anticompetitive effects. ${ }^{6}$

Although decisions such as Von's granted the Department wide discretion to initiate successful merger challenges, the Department nonetheless issued guidelines in 1968 purporting to constrain that discretion. ${ }^{7}$ Authored by Donald Turner, the first economist to head the Department's Antitrust Division (Division), those Guidelines were a straightforward application of industrial organization's "structure-conduct-performance" (SCP) paradigm. ${ }^{8}$ The 1968 Guidelines required challenges of mergers between firms with shares of four percent or more in markets with four-firm concentration ratios of at least 75 percent. In less concentrated markets, those thresholds were raised slightly, as the Department would only challenge transactions between firms with five percent or more of such markets. The 1968 Guidelines announced even stricter standards for certain subcategories of transactions, including those involving "disruptive" firms, those in markets displaying a "trend toward concentration," and those where an "insubstantial" firm possessed "an unusual competitive advantage." Although mergers that increased entry barriers were also more suspect, the Guidelines ignored precedents such as Brown Shoe Co., Inc. v. United States, which suggested that courts consider ease of entry when evaluating a merger. ${ }^{9}$ The Guidelines also relegated consideration of efficiencies to unexplained "exceptional circumstances," claiming that firms could realize any economies via internal expansion and that measurement of efficiencies is extremely difficult.

4384 U.S. 270 (1966).

5 The HHI is defined as the sum of squared market shares for each firm in an industry. Markets with HHIs below 1000 are generally considered unconcentrated.

6 See Richard A. Posner, Antitrust Law: An Economic Perspective 106 (1976); Milton Handler, Some Misadventures in Antitrust Policymaking, 76 YALE L. J. 92, 102-4 (1966).

7 See Thomas B. Leary, The Essential Stability of Merger Policy in the United States, 70 ANTITRUST L. J. 105, 108-9 (2002).

8 See Joe S. Bain, Industrial Organization (2d ed. 1968) and Donald F. Turner, The Merits of Anti-Merger Policy-A Reply to Professor Galbraith, 19 CASE WEs. L. REv. 201 (1968) for a discussion of the SCP paradigm. See Carl Kaysen \& Donald F. Turner, ANTITRUST PoLICY: AN ECONOMIC AND LEGAL ANALYSIS (1959) for application of the paradigm in the antitrust context.

9370 U.S. 294 (1962); id. at 322. 


\section{B. Post-1968 Developments Related to Merger Policy}

During the 1970s, the Department brought cases consistent with the 1968 Guidelines, including some where merging parties' market shares only modestly exceeded the Guidelines' thresholds. ${ }^{10}$ In 1977, Donald Baker, then head of the Antitrust Division, reported that the Department continued to employ the Guidelines' "clear" thresholds of " 4 percent and 4 percent in concentrated markets and 5 percent and 5 percent in less highly concentrated ones" when evaluating transactions. ${ }^{11}$ The Department spared no sector of the economy, sometimes challenging minor mergers in local markets. ${ }^{12}$ Indeed one scholar identifies several challenges where the merging parties' market shares were below Guidelines' thresholds. ${ }^{13} \mathrm{He}$ also concludes that there were usually no exceptional circumstances, such as a trend toward concentration, to justify those challenges. $\mathrm{He}$ also finds that the government, although usually victorious, lost most cases in which the merging parties' market shares were below such thresholds. ${ }^{14}$

Successful or not, such challenges could impose significant costs on parties desiring to merge. Several scholars all find that the announcement of agency challenges to mergers reduced the wealth of the merging parties, even though the challenged transactions generally did not threaten to produce market power. ${ }^{15}$ One scholar finds that the average agency challenge during the period 1950-1972 lasted 34 months and speculates that resulting negative impacts on firm wealth reflected "direct legal costs, loss of executive time, and uncertainty affecting business decision-making." 16 Moreover, courts sometimes invoked the Guidelines as persuasive authority, including in cases between private parties. ${ }^{17}$ It is no surprise that antitrust practitioners reported that the Guidelines

${ }^{10}$ For example, in United States v. G. Heileman Brewing Co., 345 F. Supp. 117 (E.D. Mich. 1972), the Department challenged a merger between firms with 7.4 and 5.5 percent shares of a purported eight state market and 2.2 and 1.8 percent shares of the national market.

11 See Donald I. Baker, Government Litigation under Section 7: The Old Merger Guidelines and the New Antitrust Majority, Remarks before the Southwestern Legal Foundation (February 24 1977).

12 See, e.g., United States v. Guardian Industries, (Civil No. C 73-383) (N.D. Ohio 1973) where the acquired firm had annual sales of $\$ 592,800$ in the greater Cleveland market for automobile replacement glass.

13 See Robert A. Rogowsky, The fustice Department's Merger Guidelines: A Study in the Application of the Rule, 6 RESEARCHES IN LAW AND ECONOMICS 135, 137-48, 142 (1984).

${ }^{14}$ See id. at 149.

15 B. Espen Eckbo \& Peggy Wier, Antimerger Policy under the Hart-Scott-Rodino Act: A Reexamination of the Market Power Hypothesis, 28 J. L. \& Econ. 119 (1985); B. Espen Eckbo, Horizontal Mergers, Collusion and Stockholder Wealth, J. FIN. ECON. 241 (1983); James Ellert, Mergers, Antitrust Law Enforcement and Stockholder Returns, 31 J. Fin. 715 (1976).

16 See James Ellert, Mergers, Antitrust Law Enforcement and Stockholder Returns, 31 J. Fin. 715, 724 (1976).

17 See, e.g., Stanley Works v. FTC, 469 F.2d 498 (2d Cir. 1972) and Allis-Chalmers Manufacturing Company v. White Consolidated Industries, Inc., 414 F.2d 506, $524-25$ (3d Cir. 1969). 
influenced firm conduct and deterred some mergers. ${ }^{18}$ Although not "law" in the conventional sense, the 1968 Guidelines clearly had a regulatory effect.

During the 1970s, numerous empirical analyses and legal developments served to undermine various aspects of the 1968 Guidelines' methodology. For instance, the Guidelines had rested upon a strong correlation between market concentration and market power, purportedly found by Joe Bain and other adherents to the SCP paradigm. ${ }^{19}$ However, Harold Demsetz demonstrated that larger firms in concentrated industries enjoyed greater profit rates than their smaller rivals within the same market. ${ }^{20}$ These findings suggested that any correlation between profits and concentration reflected scale efficiencies enjoyed by firms with larger market shares and thus not market power, the latter of which would manifest itself as enhanced profit rates for small and large firms alike. ${ }^{21}$ As a result, Demsetz said, aggressive anti-concentration policy could actually deprive the economy of significant efficiencies. ${ }^{22}$ By the mid1970s, many in the antitrust community questioned the supposed relationship between market shares and market power. ${ }^{23}$ For instance, F.M. Scherer called into question the assumption that firms exhausted available efficiencies at modest market shares, concluding that shares of greater than ten percent were sometimes necessary to exploit fully economies of scale. ${ }^{24}$ In 1968 , Oliver Williamson demonstrated that small efficiency improvements resulting from a merger to monopoly would likely exceed the allocative loss from increased market power and that relegating firms to time-consuming internal expansion could deprive society of significant benefits. ${ }^{25}$ Scholars also identified new efficiencies relevant to merger policy. One scholar, for instance, emphasized the importance of institutional arrangements that minimized shirking by corporate managers. ${ }^{26}$ Several scholars identified the market for corporate control as one such

18 See Steven M. Edwards et al., Proposed Revisions of the Department of Fustice's Merger Guidelines, 81 Colum. L. Rev. 1543, 1547-48 (1981).

19 See Joe S. Bain, Relation of Profit Rate to Industrial Concentration: American Mamfacturing 1936-1940, 65 Q. J. ECON. 293 (1951).

20 See Harold Demsetz, Industry Structure, Market Rivalry, and Public Policy, 16 J. L. \& ECoN. 1 (1973).

21 See $i d$. at 8 ("[I]f an industry is rapidly achieving workable collusive practices there is no reason to suppose that the difference between large and small firm profit rates.").

22 See id. at 49.

23 See Yale Brozen, Bain's Concentration and Rates of Return Revisited, 14 J. L. \& ECoN. 351 (1971); John S. McGhee, Why Not Deregulation for Antitrustr, 46 ANTITRUST L. J. 777 (1977); J. Fred Weston, Section 7 Enforcement: Implementation of Outmoded Theories, 49 ANTITRUST L. J. 1411 (1980); Steven M. Edwards et al., Proposed Revisions of the Department of Fustice's Merger Guidelines, 81 ColuM. L. REV. 1543, 1549-50 (1981).

24 F. M. Scherer, Economies of Scale and Industrial Concentration, 16-54 in INDUSTRIAL Concentration: The New Learning (H.J. Goldschmid et al., eds. 1974).

25 See Oliver E. Williamson, Economies as an Antitrust Defense: The Welfare Trade-offs, 58 AM. ECON. REV. 18 (1968).

${ }^{26}$ Harvey Leibenstein, Allocative Efficiency v. X-Efficiency, 56 Am. ECON. Rev. 392 (1966). 
arrangement, ${ }^{27}$ while others contended that strict antimerger regulation could render this market less effective, because horizontal rivals were best-suited to identify underperforming managers. ${ }^{28}$

Not surprisingly, in the mid-1970s, scholars began to study the impact of enforcement policies that agencies pursued during the 1960s and 1970s. These studies uniformly found that these policies were unduly aggressive. For instance, one such study found that while acquiring firms earned abnormal returns in the years leading up to merger announcements, agency challenges did not reverse such returns. ${ }^{29}$ Moreover, acquired firms earned negative abnormal returns during the period before merger announcements, leading Ellert to conclude that the challenged transactions reflected a well-functioning market for corporate control and not efforts to obtain market power. Studies by Eckbo, Stillman, and Eckbo and Wier tested two related hypotheses: (1) that merger announcements would increase the returns of the merging firms' rivals and (2) that challenges would reduce such returns. ${ }^{30}$ Each study concluded that announcements of mergers that the Department chose to challenge during the 1970s sometimes increased rivals' expected returns, consistent with a hypothesis that such transactions would result in market power. However, each study also found that the announcement of such challenges did not affect such returns. These results suggest that the Department often challenged, under the aegis of the 1968 Guidelines, transactions posing little or no threat of anticompetitive harm.

Various legal developments also undermined portions of the 1968 Guidelines during the 1970s. In United States v. General Dynamics, ${ }^{31}$ for instance, the Supreme Court held that defendants could rebut a prima facie case premised upon market shares that exceeded the Guidelines thresholds by showing that other attributes of the market and merging parties would prevent the transaction from producing competitive harm. The Court subsequently confirmed the availability of such a rebuttal, and lower courts also

${ }^{27}$ See Ralph Winter, State Law, Shareholder Protection, and the Theory of the Corporation, 6 J. LEGAL STUd. 251 (1977); Armen A. Alchian \& Harold Demsetz, Production, Information Costs and Economic Organization, 62 Am. ECon. Rev. 777, 788-89 (1972); Oliver E. Williamson, Corporate Control and Business Behavior, 97-101 (1970); Henry Manne, Mergers and the Market for Corporate Control, 73 J. POL. ECON. 110 (1965).

28 Richard A. Posner, Antitrust Law: An Economic Perspective, 111 (1976); James Ellert, Mergers, Antitrust Law Enforcement and Stockholder Returns, 31 J. Fin. 715, 716 (1976); Timothy J. Muris, The Efficiency Defense Under Section 7 of the Clayton Act, 30 Cas. Wes. L. REv. 381, 418-19 (1979); J. Fred Weston, Section 7 Enforcement: Implementation of Outmoded Theories, 49 Antitrust L. J. 1411, 1443-49 (1980); Robert Stillman, Examining Antitrust Policy towards Horizontal Mergers, 11 J. FIN. ECON. 225, 226 (1983).

29 See Ellert, Mergers, Antitrust Law Enforcement and Stockholder Returns, 31 J. FIN. at passim.

${ }^{30}$ Robert Stillman, Examining Antitrust Policy towards Horizontal Mergers, $11 \mathrm{~J}$. Fin. ECON. 225 (1983); B. Espen Eckbo \& Peggy Wier, Antimerger Policy under the Hart-Scott-Rodino Act: A Reexamination of the Market Power Hypothesis, 28 J. L. \& ECON. 119 (1985); B. Espen Eckbo, Horizontal Mergers, Collusion and Stockholder Wealth, 11 J. FIN. ECON. 241 (1983).

31415 U.S. 486 (1974). 
invoked General Dynamics as a license to consider various factors, including potential entry, in rebuttal. ${ }^{32}$ It is thus no surprise that Ghosal characterizes General Dynamics as a "landmark" decision that helped usher in a 1974 "regime shift" in the Department's enforcement policy. ${ }^{33}$

A second legal development derived from the Department's efforts to expand the scope of antimerger law. In the early 1970s, the Department convinced the Supreme Court that the Clayton Act banned certain mergers between "potential" competitors because the threat of entry by a firm outside the market could deter anticompetitive activity within it. ${ }^{34}$ The repeated invocation of the theory by the enforcement agencies, although rarely successful, presumably enhanced the plausibility of arguments that entry could counteract a proposed transaction's anticompetitive potential. Not surprisingly lawyers and judges would eventually deploy this logic in ordinary merger cases, contending that the threat of entry should counteract a prima facie case. ${ }^{35}$ The Supreme Court also announced that the purpose of the antitrust laws was to promote "consumer welfare" and rejected efforts by firms to invoke Section 7 to protect themselves from tough competition. ${ }^{36}$ Moreover, in Continental T.V. v. GTE Sylvania, the Court recognized that agreements once deemed unlawful per se could produce significant efficiencies that courts should credit when conducting Rule of Reason analysis. ${ }^{37}$ Ghosal characterizes Sylvania as another "landmark" decision, ${ }^{38}$ while Leary contends that recognition of such efficiencies, albeit under the Sherman Act, "cast a long shadow over merger jurisprudence in lower courts[.]"39

\section{The 1982 Merger Guidelines}

The election of Ronald Reagan also brought the appointment of William Baxter as Assistant Attorney General for the Antitrust Division. Before his nomination, Baxter had criticized the 1968 Guidelines for reliance on the four firm concentration index and adoption of low market share thresholds. ${ }^{40}$

32 See United States v. Citizens and Southern National Bank, 422 U.S. 86, 120-21 (1975); United States v. Marine Bank Corporation, 418 U.S. 602, 631 (1974); United States v. International Harvester Co., 564 F.2d 769 (7th Cir. 1977).

33 See Vivek Ghosal, Regime Shift in Antitrust, 7 J. Comp. L. AND ECON. 733, 769 (2011).

34 See, e.g., United States v. Falstaff Brewing Corp., 410 U.S. 526 (1973). See also Frank H. Easterbrook, Toehold Acquisitions and the Potential Competition Doctrine, 40 UnIV. CHI. L. REv. 156 (1972).

35 See, e.g., United States v. Waste Management, Inc., 743 F.2d 976 (2d Cir. 1984), which invoked the perceived potential competition doctrine in support of a determination that ease of entry could undermine a prima facie case.

${ }^{36}$ See, e.g., Brunswick Corp. v. Pueblo Bowl-o-Mat, Inc., 429 U.S. 477 (1977).

37433 U.S. 36 (1978).

${ }^{38}$ Ghosal, Regime Shift in Antitrust, 7 J. CoMP. L. \& ECON. at 769.

${ }^{39}$ See Thomas B. Leary, The Essential Stability of Merger Policy in the United States, 70 ANTITRUST L. J.105, 110 (2002).

40 See Edward Cowan, Antitrust Nominee is Reported, New York Times, Feb. 7, 1981, p. 33. 
Endorsing the HHI for measuring concentration, he opined that mergers in markets with HHIs of 1000 or 1100 were problematic if they increased the $\mathrm{HHI}$ by at least $100{ }^{41}$ After his confirmation, Baxter reiterated this belief and repeatedly reported that the Division was "reworking" the 1968 Guidelines. ${ }^{42}$

Announced on Monday June 14, 1982 at a press conference, the new Guidelines revised the 1968 Guidelines in numerous ways. For instance, the new Guidelines eschewed reliance upon individual market shares, focusing solely upon pre- and post-merger concentration and changes in concentration, as measured by HHIs, to determine whether a transaction would presumptively facilitate the collective exercise of market power. As one leading scholar explained, these new thresholds treated some transactions that would have been subject to automatic challenge under the 1968 Guidelines as entirely benign. ${ }^{43}$ For example, a merger in a market with 20 equally sized firms - resulting in an HHI of 550 - contradicted the 1968 Guidelines' strong presumption against transactions between firms with 5 percent market shares. By contrast, under the 1982 Guidelines, transactions resulting in HHIs below 1,000 were presumed lawful. ${ }^{44}$ Moreover, challenges of mergers resulting in HHIs of 1000 to 1800 were "unlikely," absent an HHI increase of at least 100 points. The 1982 Guidelines also ignored "trends" toward concentration that had previously justified challenges to otherwise innocuous transactions.

Perhaps most importantly, the concentration-based presumptions in the 1982 Guidelines were quite weak, serving only as the first step in the analysis. Although the 1968 Guidelines had ignored ease of entry, the new Guidelines provided that, regardless of concentration or changes therein, the Department was "unlikely" to challenge a transaction if entry was easy. Where entry was difficult, the 1982 Guidelines provided that the Department was "more likely than not" to challenge any transaction producing an HHI over 1000 and increasing the $\mathrm{HHI}$ more than 100. Before deciding on such a challenge, however, the Department would also consider post-merger concentration, the magnitude of the increase in concentration, and other factors including product heterogeneity, similarity of products produced by merging firms, and adoption of practices likely to facilitate coordination. If a transaction resulted in an HHI above 1800 and increased the HHI by 50-100 points, the Department would again consider these factors when deciding whether to

${ }^{41} I d$.

${ }^{42}$ See Harvey M. Applebaum, E. William Barnett, Allen C. Holmes, \& Earl E. Pollock, Panel Discussion and Interview with William Baxter, 50 ANTITRUST L. J. 151 (1981); Hearings on Oversight of Government Merger Enforcement Policy before the Senate Committee on the Judiciary, 97th Cong., 1st Sess. (statement of William J. Baxter) (October 17, 1981).

43 See Thomas Kauper, The 1982 Horizontal Merger Guidelines: Of Collusion, Efficiency, and Foilure, 71 CALIF. L. Rev. 497, 510 n. 30 (1983) (concluding that the 1982 Guidelines' HHIdriven concentration thresholds were significantly more permissive than those contained in the 1968 Guidelines).

${ }^{44}$ So far as we are aware, the Department never challenged a merger that resulted in an HHI of less than 1000 after the announcement of the 1982 Guidelines. 
challenge the transaction. Finally, the Department was "likely" to challenge transactions that resulted in $\mathrm{HHI}$ over 1800 and a change greater than 100 , without considering "other factors." Nonetheless, this prediction was still qualified by the "ease of entry" caveat.

The 1982 Guidelines also recognized a somewhat greater role for efficiencies. The introduction explained that mergers were generally beneficial and could "penalize ineffective management and facilitate the efficient flow of investment capital and the redeployment of existing productive assets." A separate section on efficiencies claimed that the new Guidelines would "in the overwhelming majority of cases... allow firms to achieve available efficiencies through mergers without interference," apparently because higher concentration thresholds created safe harbors for most transactions producing efficiencies. This section also recognized that efficiencies could justify an otherwise anticompetitive merger, albeit only in "extraordinary cases." Finally, unlike the 1968 Guidelines, the 1982 Guidelines elaborated on the standards the Department would employ when evaluating such a defense, thereby signaling the Department's willingness to consider seriously efficiency arguments.

In short, the 1982 Guidelines worked a significant change in the Department's official enforcement policy. Green, for instance, calls the 1982 Guidelines a "fundamental revision - effectively a rewrite." 45 Leading scholars agreed that these Guidelines were significantly less interventionist than the 1968 Guidelines. ${ }^{46}$ Thus, as written the 1982 Guidelines appeared to be a significant deregulatory shock for a number of American industries.

\section{ALTERNATIVE HYPOTHESES ABOUT THE IMPACT OF THE 1982 GUIDELINES}

Although the 1982 Guidelines departed substantially from the 1968 Guidelines "on paper," the real question from the perspective of regulated industries and their investors is whether this change resulted in significant deregulation of mergers in practice. As discussed in the introduction, a review of the literature suggests two answers to this question. First, some commentators state or imply that the Guidelines did not alter enforcement policy. Ghosal, for instance, finds that the Department's merger enforcement policy, as measured by the number and rate of annual merger challenges,

45 Hillary Green, Guideline Institutionalization: The Role of Merger Guidelines in Antitrust Discourse, 48 W. \& M. L. REv. 771, 781 (2006).

46 Thomas Kauper, The 1982 Horizontal Merger Guidelines: Of Collusion, Efficiency, and Failure, 71 Calif. L. Rev. 497, 510 n. 30 (1983); Eleanor Fox, The New Merger Guidelines: $A$ Blueprint for Microeconomic Analysis, 27 Antitrust Bull. 519 (1982); Donald F. Turner, Observations on the New Merger Guidelines and the 1968 Guidelines, 51 ANTITRUST L. J. 307 (1982); Hillary Green, Guideline Institutionalization: The Role of Merger Guidelines in Antitrust Discourse, 48 W. \& M. L. REv. 771 (2006) and Louis Schwartz, The New Merger Guidelines: Guide to Governmental Discretion and Private Counseling or Propaganda for Revision of the Antitrust Laws? 71 CaLIF. L. REv. 575 (1983). 
experienced a single "structural break" between 1959 and 2002, namely, in $1974 .{ }^{47} \mathrm{He}$ attributes this break, evidenced by a sharp drop in the rate of merger challenges after 1973, to the powerful Chicago School critique of the 1960s merger enforcement regime, combined with a Supreme Court dominated by Republicans receptive to a more Laissez Faire merger policy. ${ }^{48} \mathrm{He}$ also finds that the political affiliation of the President had no significant impact on the annual number of merger challenges before or after this change, even as the same political variable exercised increasing influence over nonmerger civil enforcement policy during the same period. ${ }^{49}$ Although Ghosal does not mention the 1982 Guidelines, his conclusion that there was no "structural break" in 1982 and finding that the political affiliation of the President had no impact in the merger context implies that the new Guidelines had no effect.

Like Ghosal, Leary downplays the impact of Presidential politics, contending that changes in enforcement policy during the 1980s were "foreshadowed well before the Reagan election in 1980." ${ }^{50}$ Leary also identifies 1974 as a key date, because of both General Dynamics and the publication of conference proceedings that "seriously undercut the case for a merger policy based strictly on statistical measures of concentration." $"$ As a result of these and other developments during the 1970s, he says, "substantial change was inevitable in any event," that is, regardless of who won the 1980 election. ${ }^{52}$ Thus, he concludes, after these changes "the stage was thus set" for William Baxter's merger policy expressed in the 1982 Merger Guidelines. ${ }^{53}$

Indeed, in an April, 1981 interview, Baxter opined that the 1968 Guidelines "could be improved," because they paid "inadequate attention to entry conditions and other important factors." ${ }^{54}$ In June of that same year, Attorney General William French Smith reported that the Department was "planning to revise the Merger Guidelines issued by the Department in 1968." 55 The revisions, he said, "would increase the attention given to entry

${ }^{47}$ See Vivek Ghosal, Regime Shift in Antitrust, 7 J. ComP. L. \& ECON. 733 (2011).

48 Id. at $767-68$.

${ }^{49}$ Id. at 771 .

${ }^{50}$ See Thomas B. Leary, The Essential Stability of Merger Policy in the United States, 70 ANTITRUST L. J. 105, 107 (2002).

51 See id. at 109 (citing Industrial Concentration: The New Learning (Harvey J. Goldschmid et al. eds., 1974) (publishing proceedings of 1974 Columbia Law School conference)). Leary also contends that routine review of proposed mergers pursuant to the 1976 Hart-Scott-Rodino Act helped convince the Department "that most mergers did not have the consequences predicted by once-popular assumptions about oligopoly behavior." See Leary, Essential Stability of Merger Policy, 70 Antitrust L. J. at 111.

52 See id. at 111.

${ }^{53}$ See id.

${ }^{54}$ See Harvey M. Applebaum, E. William Barnett, Allen C. Holmes, \& Earl E. Pollock, Panel Discussion and Interview with William Baxter, 50 ANTITRUST L. J. 151, 158 (1981).

55 See William F. Smith, Federal Antitrust Enforcement Goals, Remarks before the District of Columbia Bar (June 24 1981). 
conditions in assessing horizontal mergers." 56 Later that same year, William Baxter informed House and Senate Committees that, because of new economic thinking and doctrinal evolution, the 1968 Guidelines "were at variance with the state of the law, with current economic knowledge, and with the Department's actual enforcement practices." 57 In the same testimony Baxter also repeated prior statements that the Division was developing new Guidelines to replace the 1968 version. ${ }^{58}$ In the spring of 1982, Smith reported that the new Guidelines would "memorialize and formalize the standards that are already being used" to evaluate proposed transactions. ${ }^{59}$

Moreover, even before Baxter's testimony and Smith's second speech, the Department took an enforcement action that contradicted the 1968 Guidelines and reflected more recent legal and economic developments. In July, 1981, the Department announced that it was dropping a suit initiated by the Carter Administration in 1980 challenging the merger of two facing brick manufacturers in the Northeast. The 1968 Guidelines plainly required the Department to challenge the transaction, as the merging parties accounted for fourteen percent and six percent of the market, respectively. Nonetheless, Baxter's announcement of the voluntary dismissal of the challenge opined that the market was insufficiently concentrated "to support a prediction that the merger would lessen competition." 60 In short, the initial complaint followed naturally from the Guidelines, and the dismissal contradicted them, signaling a significantly more permissive policy toward horizontal mergers, along the lines that Baxter had endorsed earlier in the year.

Deregulatory announcements generally take place after a lengthy political process involving numerous independent actors, with the result that market actors anticipate regulatory change. ${ }^{61}$ One might argue by analogy that various official statements, along with developments in the case law such as General Dynamics, the post-1973 reduction in enforcement activity, and the dismissal of the facing brick merger suit, all signaled to market actors that the Department's enforcement policy had departed significantly from that expressed in the 1968 Guidelines well before the June, 1982 announcement of the new Guidelines. Moreover, these statements also presaged some aspects of then-current enforcement policy that the new Guidelines would, as the Attorney General had said, merely "memorialize," such as reliance on

$56 \mathrm{Id}$.

57 See Hearings on Oversight of Government Merger Enforcement Policy before the Senate Committee on the Judiciary, 97th Cong., 1st Sess. (statement of William J. Baxter) (October $17,1981)$.

58 See id.

59 See William F. Smith, Changing Enforcement Policy: Remarks before the American Bar Association Antitrust Spring Meeting, 51 ANTITRUST L. J. 95, 97 (1982).

60 See U.S. Drops Trust Suits Against Mack, Two Others, New York Times, July 9, 1981, at D1.

61 See John J. Binder, Measuring the Effects of Deregulation with Stock Price Data, 16 RAND J. ECON. 167 (1985). 
the HHI and greater attention to entry conditions. If so, the official announcement of the new Guidelines should have had little or no impact upon the market value of regulated enterprises.

Shortly after the June 14 announcement, various observers declared that the new Guidelines wrought little or no change in existing enforcement policy. A June 24 report quoted former enforcement officials and leading practitioners who opined that the new Guidelines were merely "an embodiment of current enforcement practice" that "codif[ied] the analysis that [the Department] has actually been using." $" 62$ Thus, it was said, the new Guidelines recognized "arguments [practioners] had been making ... for a number of years[,]" with the result that practitioners "won't do anything differently." report in the New York Times recounted that "most experts agree that [the new Guidelines] contain no bombshells" and paraphrased Baxter's view that the new standards "just codify and refine the changes that department policy has undergone since the last guidelines were issued in 1968." ${ }^{.64}$ Indeed, two leading antitrust practitioners opined on June 21st that the 1982 Guidelines contained "no real surprises." ${ }^{55}$ Baker and Blumenthal concluded that the 1982 Guidelines' higher concentration thresholds were "an accurate reflection of the government's enforcement policies-not only under the present administration, but as the policies have stood for some time." ${ }^{66}$ Overall, they said, the new Guidelines fell "within the mainstream" when it came to horizontal mergers and also "adhere[d] fairly closely to the current state of the law on the standards by which horizontal mergers are to be judged." ${ }^{67}$ Any differences between the Guidelines and current law, they said, were "cosmetic." 68

There is, however, an alternative account of the impact of the 1982 Guidelines. This account exemplifies the view expressed by Clougherty and Seldeslachts that changes in merger enforcement policy are "difficult to anticipate" because they "represent politically-driven exogenous shocks to merger policy." ${ }^{69}$ In this vein, several scholars and practitioners claim or imply that the 1982 Guidelines did alter enforcement policy. Lawrence White helped draft the 1982 Guidelines and reports his "horseback sense" that antimerger policy was more lenient during the Reagan Administration than

62 See Antitrust Practitioners React Favorably to New Merger Guidelines, 42 ANTITRUST \& TRADE REG. REPORTER 1315 (Bureau of National Affairs 1982).

63 See id.

64 See Tamar Lewin, Skepticism on Merger Guidelines, New YoRK TIMES, February 7, 1981, at D1.

65 Joe Sims \& William Blumenthal, New Merger Guidelines Provide No New Real Surprises, LEGAL Times, June 21, 1982 at 1.

${ }^{66}$ Donald I. Baker \& William Blumenthal, The 1982 Guidelines and Preexisting Law, 71 CALIF. L. REV. 311, 332 (1983).

67 Id.

${ }^{68} \mathrm{Id}$.

${ }^{69}$ Joseph A. Clougherty \& Jo Seldeslachts. The Deterrence Effects of U.S. Merger Policy Instruments, 29 J. L., ECON. \& ORG. 1114, 1131 (2013). 
before and that such leniency was in part "a product of the somewhat greater leniency that [was] built into the Guidelines themselves."70 Another scholar acknowledges significant evolution in enforcement policy during the 1970s and also opines that such evolution may well have continued during a second Carter Administration. ${ }^{71}$ At the same time, he also states that the 1982 Guidelines served as the "conceptual foundation" for the "1980s accelerat [ion] in the loosening in controls that had begun in the latter half of the 1970s."72 Two other scholars concede that courts and agencies "relaxed... unduly aggressive antimerger policies of the 1960s," with the result that the Department brought fewer and narrower cases in the late 1970s. ${ }^{73}$ However, they also contend that, as of 1980 , the line between lawful and unlawful transactions was "unsettled" and that "no clear articulation [had] emerged of the evolving narrower view of the reach of Section Seven [of the Clayton Act]." ${ }^{74}$ Thus, they say, the Reagan Administration "inherited a merger policy that was in disarray[,]" "vigorously seized their opportunity to alter and clarify merger policy[,]" and "substantially reshaped merger policy into a form never seen or administered since the 1950 Celler-Kefauver amendments."75 They also state that the 1982 Guidelines were part of this effort. To support this claim, they correctly note that the rate of merger investigations and challenges fell precipitously in 1982-1986 compared with the rate in 1979-1980. ${ }^{76}$ Other scholars have asserted that the Department's relaxation of antimerger enforcement mattered a great deal and, in fact, helped fuel the early 1980 s merger boom. ${ }^{77}$

It should also be noted that statements, testimony and enforcement decisions left considerable uncertainty about the precise content of enforcement policy before the June 14 announcement. For instance, some observers had surmised that the new Guidelines would treat markets with HHIs over 1,600 as "highly concentrated," while others had speculated that the figure would

${ }^{70}$ See Joseph A. Grundfest, Gregg Jarrell, Steven C. Salop, \& Lawrence J. White, Panel Discussion: Corporate Takeovers and Public Policy, 311-32 in CoRporate TAKeovers: Causes AND CONSEQUENCES (Alan J. Auerbach, ed. 1988).

${ }^{71}$ William E. Kovacic, The Modern Evolution of U.S. Competition Policy Enforcement Norms, 71 Antitrust L. J. 377, 437-38 (2003).

${ }^{72}$ Id. at 435.

${ }^{73}$ See Thomas Krattenmaker \& Robert Pitofsky, Antitmust Merger Policy and the Reagan Administration, 33 ANTITRUST Bull. 211, 214 (1988).

${ }_{74} \mathrm{Id}$.

$75 \mathrm{Id}$.

${ }^{76} \mathrm{Id}$. at 213.

77 See e.g. William G. Shepherd, Public Policies toward Business, 211 (1991) (attributing "greatest merger wave" to "more lenient Reagan policies toward mergers [which] stirred a vast, frenzied merger boom."); id. at 212 (claiming that "enforcement activity virtually ceased" during the 1980s); id. at 221 (describing "[n]ew guidelines issued in 1982 and 1984" as establishing more permissive enforcement standards); Linda Brewster Stearns and Kenneth D. Allan, Economic Behavior in Institutional Environments: The Corporate Merger Wave of the 1980s, 61 AM. SOCIOL. REv. 699, 703-706 (1996). 
be $2,000 .{ }^{78}$ Moreover, market actors are interested in more than just the content of current enforcement policy. They also care about the stability and durability of that policy. Once detailed guidelines are in place, agencies that wish to alter enforcement policy must incur the cost of drafting new guidelines or suffer the reputational consequences of taking (new) enforcement positions that contradict standing guidelines. Thus, the issuance of new guidelines can function as a credible commitment that the policy contained therein will be more durable than a policy communicated by a series of enforcement decisions, speeches and congressional testimony. Even if they simply replicated exactly an enforcement policy that was already in place, the 1982 Guidelines presumably sent an important signal about the durability of that policy.

\section{TESTING THE IMPACT OF THE 1982 GUIDELINES}

Most who opine about the impact of the 1982 Guidelines offer little or no hard evidence to support their views. Those who do offer evidence generally focus on the raw number of annual merger challenges or the ratio of such challenges to the overall number of mergers. ${ }^{79}$ However, as White observes, such metrics may not be useful proxies for the substantive content of enforcement policy, as "the clarity or fuzziness of a standard" may have far greater impact on the number of challenges than the standard's substantive content. ${ }^{80}$

Unlike other proponents of alternative views, Sapozhinikov attempts a rigorous empirical test of the impact of various sets of Merger Guidelines on the number and type of mergers in the U.S. economy. ${ }^{81}$ She begins by positing that changes in merger enforcement policy are "not abrupt but rather gradual," and that any variable that serves as a proxy for such change must reflect its continuous and evolving nature. Her model therefore employs a splined time trend variable as a proxy for changes in government policy toward mergers. The quarterly time trend variable is splined in the quarter following the issuance of new Guidelines in 1968, 1982, 1984 and other times. The study concludes that a 1982 change in enforcement policy resulted in increased horizontal and conglomerate merger activity and that the impact

${ }^{78}$ See fustice Department Unveils Long-Awaited Revisions to Merger Guidelines; FTC Issues Statement on Mergers, 42 ANtitrust \& TRAde Reg. Reporter 1251 (Bureau of National Affairs 1982); James Campbell, Steven M. Edwards, \& James Egan, Panel Discussion: Merger Guidelines: Proposals for Change, New York State Bar Association 1982 Antitrust Law Symposium (January 27. 1982); Robert E. Taylor, U.S. Eases Merger Guidelines, Allowing Somewhat More Concentrated Markets, Wall Street Journal (June 15 1982).

79 See, e.g., Vivek Ghosal, Regime Shift in Antitrust, 7 J. ComP. L. \& ECON. 733, 748 (2011) and Thomas Krattenmaker \& Robert Pitofsky, Antitrust Merger Policy and the Reagan Admimistration, 33 AntrTRust Bull. 211, 214 (1988).

${ }^{80}$ See Joseph A. Grundfest, Gregg Jarrell, Steven C. Salop, \& Lawrence J. White, Panel Discussion: Corporate Takeovers and Public Policy, 311-332 in Corporate TAKeOvers: CaUSES AND ConseQuences (Alan J. Auerbach, ed. 1988).

${ }^{81}$ Margarita Sapozhinikov, Mergers and Government Policy, Boston College Working Papers in Economics, Series Number 656 (unpublished manuscript 2006). 
of the change grew over time. At the same time, an alternate specification of the same change, namely, a binary dummy that takes on a positive value in the third quarter of 1982, generates a negative and insignificant result.

The objective of this paper is to test the hypothesis that the 1982 Guidelines were perceived as a real change in enforcement policy that would result in substantial deregulation of mergers throughout the economy. More specifically, we test whether market actors perceived the guidelines as a deregulatory change by examining the market capitalization of firms subject to U.S. merger policy. If the guidelines are perceived as a real policy change, the market should recognize the increased prospect of mergers that could produce private benefits by creating market power, generating efficiencies, or both. Thus, rational investors should bid up the prices of those companies now more likely to engage in mergers producing such benefits. Additionally, as some scholars have noted, rivals might have a comparative advantage in identifying mismanaged firms, with the result that reducing antitrust barriers to horizontal transactions could increase the probability that mismanaged firms would be the target of hostile takeovers, reduce anticipated agency costs and increase expected profitability. ${ }^{82}$ Anticipating these effects, investors should again bid up the share prices of deregulated firms. The second such effect, it should be noted, would not manifest itself as a change in the number of enforcement actions or actual mergers. Thus, our analysis is designed to capture an impact of regulatory change that other methodologies would miss.

We employ the standard event study methodology described by MacKinlay and Bhagat and Romano to test this hypothesis. ${ }^{83}$ Event studies are used to analyze the behavior of firm stock prices around a particular event to determine whether or not the event results in a change in the stock's performance. Event studies are a mainstay in the financial literature but are also employed widely in other areas including the field of law and economics. The structure of an event study is relatively straightforward. In the market model, a pre-event estimation window is used to model the relationship between the firm's stock price and some measure of the overall market. Let $R_{i t}$ be the price of firm $i$ 's stock at time $t$ and $M_{t}$ a measure of the overall market at time $t$. An ordinary least squares regression is then used to estimate

$$
R_{i t}=\alpha_{i}+\beta_{i} M_{t}+\varepsilon_{i t}
$$

82 See, e.g., Robert Stillman, Examining Antitmust Policy towards Horizontal Mergers, $11 \mathrm{~J}$. FIN. ECON. 225 (1983). See also n. 28, supra (collecting authorities contending that horizontal rivals were well-positioned to identify and acquire firms directed by shirking managers).

${ }^{83}$ Sanjai Bhagat \& Roberta Romano, Event Studies and the Law: Part I Technique and Corporate Litigation, 4 Am. L. \& ECON. Rev. 141 (2002); Sanjai Bhagat \& Roberta Romano, Event Studies and the Law: Part II: Empirical Studies and Corporate Law, 4 AM. L. \& ECON. REv. 380 (2002); A. Craig MacKinlay, Event Studies and Finance, 35 J. ECON. LrT. 13 (1997). See also Jonah B. Gelbach \& Jonathan Klick, Empirical Law and Economics, Ch. 3.5.1 in OxForD Handbook of Law and Economics (Francisco Parisi ed., Oxford 2017). 
where $\alpha_{i}$ and $\beta_{i}$ are firm-specific coefficients and $\varepsilon_{i t}$ is the error term for all of the trading days during the estimation window. This model is called a market model because the $M_{t}$ variable controls for changes in the price of the stock that are due to market-wide factors.

The researcher then identifies a period of time around the event to be studied-an event window-during which a stock market response, if any, to the event is expected. The estimated coefficients for firm $i$ are then used in conjunction with the market measures, $M_{t}$, to predict the expected return for firm $i$, that is

$$
E\left[R_{i t}\right]=\alpha_{i}+\beta_{i} M_{i}
$$

for all trading days during the event window. The abnormal return for firm $i$ on a given day during the event window, $A_{i t}$, is the difference between the actual price for firm $i$ 's stock and the predicted price, or

$$
A_{i t}=R_{i t}-E\left[R_{i t}\right]=R_{i t}-\alpha_{i}-\beta_{i} M_{t}
$$

For event windows longer than a day, the researcher usually computes the cumulative abnormal return as the sum of the daily abnormal returns across the period of the event window. If the event has no systematic effect on the firm's stock price, in expectation the mean abnormal return should be zero. The researcher can perform statistical tests on either the daily or cumulative abnormal returns against the null hypothesis that mean abnormal performance equals zero. Alternatively the researcher can use the cumulative abnormal return as the dependent variable in a cross-section regression, as we do in this paper, to determine whether firm characteristics systematically affect a firm's cumulative abnormal return during the event window.

Our sample for the analysis consists of publicly traded firms that were part of the Standard \& Poor's (S\&P) 500 Index at the time of the announcement, as identified in the 1982 Stock Market Encyclopedia of the S\&P 500. ${ }^{84}$ Thus we began with 500 firms in our sample. We then excluded four firms from the sample that were themselves the results of recent mergers. Next we dropped twelve firms from the sample because they were not traded on the New York Stock Exchange (NYSE) and their prices are reported differently from those of firms traded on the NYSE. Finally, we excluded six firms from the sample because we were unable to obtain a complete set of stock market prices for the period we studied. This left 477 firms in our sample. For the analysis, we utilize two different estimation windows to estimate the coefficients that we subsequently employ to predict the expected price of each firm's stock during the event window. The first estimation window (EST30)

${ }^{84}$ Standard and Poor's Corporation, Stock Market Encyclopedia of the S\&P 500 (1982). 
begins 60 trading days before the June 14, 1982 announcement and ends 30 trading days before the announcement (March 18, 1982 through April 30, 1982). The second estimation window (EST300) begins 330 trading days before the announcement and also ends 30 trading days before the announcement (April 6, 1981 through April 30, 1982). Following the market model, we regress the daily returns of each firm during the estimation windows against a daily market index. We use two different market indices for our analysis, the Wilshire 5000 and the S\&P $500 .{ }^{85}$

We also use two different event windows: the first (EV5) begins two trading days before the announcement and ends two trading days after the announcement (June 10, 1982 through June 16, 1982), while the second (EV9) begins four trading days before the announcement and ends four trading days after (June 8, 1982 through June 18, 1982). Again following standard methodology, we use the estimation coefficients from the market model regressions to predict returns for each firm's stock during the event window. We then compare the daily predicted returns with actual returns and calculate cumulative abnormal returns for the two event windows for each firm in our sample.

To test the effect of the announcement of the 1982 Guidelines on firms' cumulative abnormal returns (CARs), we estimate a standard cross-sectional treatment effects model. We use data on firm and industry characteristics including the firm's nationality, the primary industry in which the firm participates, whether a particular industry is exempt from antitrust regulation of mergers, and concentration measures for various industries to identify potential control groups that are unlikely to be affected by the announcement of the 1982 Guidelines. ${ }^{86}$ We then compare the CARs of the control group with those of the treatment group using a simple ordinary least squares regression with a binary treatment dummy.

We constructed a series of different treatment/control groups for the analysis. In particular, we sought to identify different control groups that, because of observable characteristics, should be unaffected by the new Guidelines. Following Black and Khanna (2007) and Litvak (2007), we

85 Data on daily stock prices and the two market indices were obtained from the Center for Research in Security Prices (CRSP) database.

86 We took the data on firm nationality and jurisdiction of incorporation from the 1982 Stock Market Encyclopedia of the S\&P 500. We found each firm's primary industry, defined at the four digit level, in the 1981 Ward's Directory of the 55,000 Largest U.S Corporations. See WARD'S DiRECTORY OF 55,000 LARGEST U.S. CORPORATIONS (1981). We obtained the HHIs at the four digit level for manufacturing firms from the 1982 Census of Manufactures. See Department of Commerce, 1982 Census of Manufactures (1985). For nonmanufacturing firms, we obtained firm-level sales data for industries defined at the three digit SIC level from the 1981 Ward's Directory. We used these data to calculate HHIs for each nonmanufacturing industry with one or more firms in our sample. We then attributed the resulting HHIs to each nonmanufacturing firm in the industry in question. As a result, two nonmanufacturing firms that occupy the same industry defined at the three digit SIC level would exhibit the same HHI, even if each occupies a different four digit SIC industry. 
identified groups that could serve as benchmarks for comparison to the remaining firms in the sample whose observed characteristics made their returns more susceptible to the announcement. ${ }^{87}$ Table 1 presents our results for various models (that is, treatment/control groups) for four different sets of estimation/event window parameters. In each regression, standard errors are clustered at the SIC code level.

Model 1 is the baseline model and does not employ a treatment group. Model 2's treatment group includes all firms in industries subject to the Clayton Act, excluding energy utilities, telecommunications firms, and firms in industries with HHI's greater than 1800. Because both airlines (SIC 4511) and railroads (SIC 4011) were exempt from the Clayton Act during this period, they are part of the control group. ${ }^{88}$ Additionally, firms headquartered outside the United States are in the control group as presumably most mergers involving such firms only implicate foreign markets and are thus beyond the effective scope of U.S. antitrust regulation. Thus, changes in U.S. law or enforcement policy should have little, if any, impact upon such firms' merger prospects and thus firm value. ${ }^{89}$ Energy utilities and telecommunications firms are also included in the control group. Until the 1990s regulatory constraints confined the operation of energy utilities to particular states, thus severely limiting if not completely denying their ability to merge. ${ }^{90}$ Indeed, nearly all telecommunications firms also enjoyed statutory monopolies confined to particular states during this period. ${ }^{91}$ Hence, a change in merger

87 See Bernard S. Black \& Vikramaditya S. Khanna, Can Corporate Governance Reforms Increase Firms' Market Values? Evidence from India, 4 J. OF EMPIRICAL LEGAL STUD. 749 (2007); Katherine Litvak, The Impact of the Sarbanes-Oxley Act on Non-U.S. Companies Cross-Listed in the U.S, 13 J. CORP. FIN. 195 (2007).

88 The Department of Transportation possessed exclusive jurisdiction to review airline mergers pursuant to a less interventionist standard than that contained in the Clayton Act. See Willard K. Tom, Antitrust LAw Developments (ThiRd), 1145-46 (American Bar Association 1992); Marvin C. Cohen, Antitrust Implications of Airline Deregulation, 28 Antitrust Bull. 131 (1983); Comment, The Airline Merger Cases: CAB Application of Section 7 after Deregulation, 12 TRANSP. L. J. 139 (1980). This authority expired in 1988, at which point the Clayton Act, enforced by the Department of Justice, applied to airlines. See Tom, Antitrust Law Developments (Third), at 1147. Tom also reports that the Interstate Commerce Commission possessed exclusive jurisdiction over railroad mergers pursuant to a "public interest" standard during this period.

89 Similarly, one scholar uses Canadian firms as a control group to test the impact of U.S. merger enforcement policy on vertical mergers. See B. Espen Eckbo, Mergers and the Vahe of Antitrust Deterrence, 47 J. FIN. 1005 (1992).

90 See David A. Becher, J. Harold Mulherin, \& Ralph A. Walking, Sources of Gains in Corporate Mergers: Refined Tests from a Neglected Industry, 47 J. FIN. AND QUANT. ANAL. 57, 59 (2012).

91 The Telecommunications Act of 1996 required states to cease granting such monopolies. See Peter W. Huber, Michael K. Kellogg and John Thorne, The Telecommunications ACT of 1996 (1996). Additionally, the United States did not challenge a single merger in the telecommunications or energy utility industry, although the 1968 Guidelines were in effect. See American Bar Association, 1982 Merger Case Digest (1984). 
Table 1. Regression results for the cumulative abnormal return treatment effects models

\begin{tabular}{|c|c|c|c|c|}
\hline $\begin{array}{l}\text { Estimation window } \\
\text { Event window } \\
\text { Estimation price index }\end{array}$ & $\begin{array}{l}\text { EST30 } \\
\text { EV5 } \\
\text { Wilshire } \\
\text { 5000 }\end{array}$ & $\begin{array}{l}\text { EST30 } \\
\text { EV9 } \\
\text { Wilshire } \\
5000\end{array}$ & $\begin{array}{l}\text { EST300 } \\
\text { EV5 } \\
\text { Wilshire } \\
\text { 5000 }\end{array}$ & $\begin{array}{l}\text { EST30 } \\
\text { EV5 } \\
\text { S\&P } \\
500\end{array}$ \\
\hline \multicolumn{5}{|l|}{ Model 1} \\
\hline Constant & $\begin{array}{r}-3.17^{*} \\
(1.50)\end{array}$ & $\begin{array}{r}-6.41^{*} \\
(2.77)\end{array}$ & $\begin{array}{r}-3.47^{*} \\
(1.59)\end{array}$ & $\begin{array}{r}-8.33^{*} \\
(1.25)\end{array}$ \\
\hline \multicolumn{5}{|l|}{ Model 2} \\
\hline $\begin{array}{l}\text { Nonutilities, subj. to } \mathrm{CA} \text { in industries with } \\
\mathrm{HHI}<1800(N=331) \\
\text { Constant }\end{array}$ & $\begin{array}{l}-2.77 \\
(3.77) \\
-1.25 \\
(3.40)\end{array}$ & $\begin{array}{l}-5.67 \\
(6.81) \\
-2.48 \\
(6.08)\end{array}$ & $\begin{array}{l}-1.46 \\
(3.85) \\
-2.46 \\
(3.42)\end{array}$ & $\begin{array}{r}-0.20 \\
(2.89) \\
-8.19^{*} \\
(2.51)\end{array}$ \\
\hline \multicolumn{5}{|l|}{ Model 3} \\
\hline $\begin{array}{l}\text { Nonutilities, subj. to CA in industries with } \\
1000<\mathrm{HHI}<1800(N=58)\end{array}$ & $\begin{array}{r}8.82^{*} \\
(2.74)\end{array}$ & $\begin{array}{l}17.41^{*} \\
(5.25)\end{array}$ & $\begin{array}{r}7.80^{*} \\
(2.98)\end{array}$ & $\begin{array}{r}6.78^{*} \\
(2.29)\end{array}$ \\
\hline Constant & $\begin{array}{r}-4.24^{*} \\
(1.62)\end{array}$ & $\begin{array}{r}-8.53^{*} \\
(2.96)\end{array}$ & $\begin{array}{r}-4.42^{*} \\
(1.73)\end{array}$ & $\begin{array}{r}-9.15^{*} \\
(1.37)\end{array}$ \\
\hline \multicolumn{5}{|l|}{ Model 4} \\
\hline $\begin{array}{l}\text { Firms in industries with } 1000<\mathrm{HHI}<1800 \\
(N=64)\end{array}$ & $\begin{array}{l}13.07^{*} \\
(4.37)\end{array}$ & $\begin{aligned} 25.60^{*} \\
(8.42)\end{aligned}$ & $\begin{array}{l}11.67^{*} \\
(4.27)\end{array}$ & $\begin{array}{l}8.08^{*} \\
(2.80)\end{array}$ \\
\hline Nonutilities, subj, to $\mathrm{CA}(N=409)$ & $\begin{array}{c}-10.01+ \\
(5.48)\end{array}$ & $\begin{array}{c}-18.52+ \\
(9.53)\end{array}$ & $\begin{array}{c}-9.06^{*} \\
(4.44)\end{array}$ & $\begin{array}{c}-5.56+ \\
(3.09)\end{array}$ \\
\hline Constant & $\begin{array}{c}3.66 \\
(5.07)\end{array}$ & $\begin{array}{c}6.03 \\
(8.62)\end{array}$ & $\begin{array}{c}2.73 \\
(3.86)\end{array}$ & $\begin{array}{c}-4.65+ \\
(2.68)\end{array}$ \\
\hline
\end{tabular}

OLS regression, std. errors (in parentheses) clustered at the 4-digit SIC code level. CA, Clayton Act.

*Indicates statistical significance at the $5 \%$ level.

+ Indicates statistical significance at the $10 \%$ level.

enforcement policy would have no deregulatory effect impacting the market value of such firms.

The final group of firms in the Model 2 control group are firms in highly concentrated industries, that is, where high concentration is defined as industries with HHIs of 1800 or more. The rationale for using these firms as controls is that both sets of Guidelines were hostile to transactions in highly concentrated markets, with the result that the 1982 change would have little or no impact on firms in such markets. More specifically, although the 1982 Guidelines do not explicitly condemn mergers in industries with HHI's above 1800, they do condemn mergers in such industries that produce an increase in the HHI over 100 points. Although there are two potential defenses for challenged mergers-that new entry would counteract any anticompetitive effects or that the merger produced significant efficiencies that counteracted any harm - for mergers in highly concentrated markets, these defenses would not be easy to argue. ${ }^{92}$ Thus, the 1982 Guidelines would still

92 For instance, to the extent concentration reflected scale or other economies, merger proponents invoking purported ease of entry would have to establish that new entrants could 
have required a challenge to the majority of significant mergers resulting in an HHI over 1800 where the change in the HHI exceeded 100. To determine the HHI for the industries in our analysis, we followed other scholars and treated manufacturing industries defined by 4-digit SIC codes as relevant markets. ${ }^{93}$ For nonmanufacturing firms, we employed 3-digit SIC codes to identify such markets. ${ }^{94}$

For Model 3, we expanded the control group by adding all firms in unconcentrated industries, defining as "unconcentrated" industries with HHIs below 1000. The rationale for adding these firms to the control group rests on the assumption, articulated by one scholar, that enforcement policy evolved in a less interventionist direction during the late 1970s. ${ }^{95}$ If so, the announcement of the 1982 Guidelines would not impact the merger prospects of firms in these industries, as mergers between such firms were unlikely to be targeted in the early 1980 s even if they contravened the 1968 Guidelines. ${ }^{96}$ This expansion could also accommodate the possibility that

capture a significant share of the market's sales shortly after entering the market. Moreover, the 1982 Guidelines required merger proponents to prove any efficiencies by clear and convincing evidence and required greater efficiencies the greater the level of concentration. Finally, the 1982 Guidelines provided that the Department would "resolve close cases in favor of challenging the merger" when the resulting HHI was over 1800 .

93 See e.g. Joseph A. Clougherty \& Jo Seldeslachts, The Deterrence Effects of U.S. Merger Policy Instruments, 29 J. L., ECON. \& ORG. 1114 (2013); Margarita Sapozhinikov, Mergers and Government Policy, Boston College Working Papers in Economics, Series Number 656 (unpublished manuscript 2006); B. Espen Eckbo, Horizontal Mergers, Collusion and Stockholder Wealth, 11 J. Fin. Econ. 241 (1983); Joe S. Bain, Relation of Profit Rate to Industrial Concentration: American Manufacturing 1936-1940, 65 Q. J. ECoN. 293 (1951). Some have contended that the industries identified by four digit SIC Codes can be poor proxies for relevant antitrust markets. See e.g. Russell W. Pittman \& Gregory J. Werden, The Divergence of SIC Codes from Antitrust Markets: Indications from Department of Fustice Merger Cases, 33 ECON. LETTERS 283 (1990). However, critics admit that "hundreds" of articles in the industrial organization literature have employed four digit SIC Codes in this manner. See Gregory J. Werden, The Divergence of SIC Industries from Antitrust Markets: Some Evidence From Price Fixing Cases, 28 ECON. LETTERS 139 (1988). Moreover, if contemporary market actors perceived that regulators would act as though such categories correspond to relevant markets, they presumably treated such categories as relevant markets for the purpose of assessing whether a contemplated transaction was subject to challenge. In this connection, it should be noted that the Federal Trade Commission's compilation of large mergers consummated between 1949 and 1979 classified such transactions by four digit SIC Code and treated as "horizontal" mergers between firms sharing the same such code. See U.S. Federal TRAdE Commission, Bureau of Economics Statistical Report on Mergers and ACQUISITIONS 1979 (1981). However, the same compilation also treated as horizontal some transactions between firms with different four digit codes.

${ }^{94}$ Ideally, we would have used four digit SIC codes for nonmanufacturing industries as well. However, we were unable to obtain the necessary data to compute HHIs for nonmanufacturing industries at the four digit SIC code level.

95 See Thomas B. Leary, The Essential Stability of Merger Policy in the United States, 70 ANTITRUST L. J. 105, 111 (2002).

${ }^{96}$ However, one scholar contends that the Department continued to challenge transactions in unconcentrated markets into the early 1980s. See Robert A. Rogowsky, The fustice 
Baxter's own statements and enforcement decisions signaled that the Department's enforcement policy had changed in a deregulatory direction before the Department announced the new 1982 Guidelines. If one or both of these surmises is correct, then inclusion of such firms in the control group is warranted. For this final model, the control group encompasses the majority of firms, 419 , leaving only 58 firms in the treatment group.

We turn now to the results of these models as shown in Table 1. For each model, we provide a brief description of the treatment dummy and indicate the number of firms in the treatment group. We also show the results for four different combinations of three parameters (that is, estimation window, event window, estimation price index). Results for the other parameter sets were generally consistent with those for the parameter sets shown and are available from the authors upon request. We begin by noting that the baseline Model 1 shows significant negative coefficients for the constant term across all four sets of parameters shown in the Table. These results suggest that the S\&P 500 firms as a group experienced negative CARs relative to both market indices during the event window. ${ }^{97}$ Turning next to Model 2, which has the largest treatment group and smallest control group, note that the treatment group does not have a significant coefficient for any of the four sets of parameters and the constant only has a significant coefficient for the final set of parameters. However, all of the coefficients are negative and the combined value of the two coefficients in Model 2 is similar to the value of the coefficient on the constant term in Model 1.

Model 3 exhibits a very different pattern. For all four sets of parameters, the coefficient on the treatment dummy is positive and statistically significant and the coefficient on the constant term is negative and statistically significant. Moreover, the positive coefficient on the treatment dummy is relatively large-for three of the four sets of treatment parameters (those using the Wilshire 5000 market index) it is larger than the negative coefficient on the constant term, thereby resulting in a net positive CAR for firms in the Model 3 treatment group. These results suggest that announcement of the 1982 Guidelines functioned as a deregulatory shock for the Model 3 treatment group. Recall that this treatment group consists of firms that are not exempt from antitrust regulation of mergers, are not state-regulated utilities, and are in industries with HHIs between 1000 and 1800. These firms experienced significantly positive CARs during the event window.

There are two defining characteristics for firms in the Model 3 treatment group: the market concentration for the industries in which the firms operate

Department's Merger Guidelines: $A$ Study in the Application of the Rule, 6 RESEARCHES IN LAW AND ECONOMICS 135, 154-59 (1984).

${ }^{97}$ We do use value-weighted market indices. Theoretically, a relatively small shift in the price of a large company can heavily influence the value of the index when prices are weighted by firm value. However, we also find a significant negative coefficient on the constant term when we use equal-weighted indices. 
and the fact that federal merger policy is in force for these firms. To determine which characteristic is driving the results, we created an additional model, Model 4, with two different treatment dummies: one for firms with HHIs between 1,000 and 1,800 (including exempt firms, energy utilities, and telecommunications firms in such industries) and one for firms that are neither energy utilities nor telecommunications firms nor exempt from the Clayton Act. The overlap of these two groups includes the 58 firms in the Model 3 treatment group. Interestingly, the coefficient on the dummy for firms in industries with HHIs between 1000 and 1800 is positive and significant showing that these firms had higher CARs than firms in either unconcentrated or highly concentrated industries. The coefficient on firms in the second group is negative and significant. Thus, it appears that differences in market concentration, and not membership in particular industries, drives the results in Model 3. These results suggest that the announcement of the 1982 Merger Guidelines resulted in a positive increase in firm value for firms with $\mathrm{HHI}$ between 1,000 and 1,800 that were subject to Clayton Act regulation during this period.

Comparing results across the four different parameter sets, note that in all cases the signs and significance of coefficients is consistent across the three parameter sets that use the Wilshire 5000 index. Thus, the use of a longer event window or a longer estimation window has no effect on our qualitative findings. Of course, using a longer event window results in quantitatively larger coefficients, since the number of trading days over which the CARs are summed is higher. In comparison, the use of a longer estimation window does not result in any consistent change to the size of the coefficients. The use of the S\&P 500 Index instead of the Wilshire 5000 index does result in a significant coefficient on the constant term in three of the models. Additionally, in all models, the coefficient on the constant in the S\&P 500 parameter set is lower than those in the Wilshire 5000 parameters sets, indicating a larger negative CAR for firms in the control groups of each model. This suggests that the Wilshire 5000 serves as a better predictor of market driven price changes for firms in the control group than the S\&P 500 .

\section{INTERPRETATION OF RESULTS AND ADDITIONAL TESTS}

The results for Models 3 and 4 tend to support the second, alternative account of the impact of the 1982 Merger Guidelines. That is, these results suggest that promulgation of the 1982 Guidelines conveyed important new information to market actors about the content of the Department's merger enforcement policy. In particular, these actors perceived the announcement as a signal of a more relaxed enforcement posture vis a vis firms in industries with HHIs between 1000 and 1800 . Note that for these firms, the 1982 Guidelines articulate a substantially less intrusive enforcement policy than their 1968 predecessors on paper, and that market actors apparently interpreted the announcement 
Table 2. Sensitivity analysis for market concentration

\begin{tabular}{|c|c|c|c|c|}
\hline $\begin{array}{l}\text { Estimation window } \\
\text { Event window } \\
\text { Estimation price index }\end{array}$ & $\begin{array}{l}\text { EST30 } \\
\text { EV5 } \\
\text { Wilshire } \\
5000\end{array}$ & $\begin{array}{l}\text { EST30 } \\
\text { EV9 } \\
\text { Wilshire } \\
5000\end{array}$ & $\begin{array}{l}\text { EST300 } \\
\text { EV5 } \\
\text { Wilshire } \\
5000\end{array}$ & $\begin{array}{l}\text { EST30 } \\
\text { EV5 } \\
\text { S\&P } \\
500\end{array}$ \\
\hline $\begin{array}{l}\text { Nonutilities, subj. to CA in industries with } 1800< \\
\text { HHI }(N=78)\end{array}$ & $\begin{array}{l}-3.56 \\
(3.26)\end{array}$ & $\begin{array}{l}-6.02 \\
(5.98)\end{array}$ & $\begin{array}{l}-5.13 \\
(3.08)\end{array}$ & $\begin{array}{c}-3.91+ \\
(2.39)\end{array}$ \\
\hline $\begin{array}{l}\text { Nonutilities, subj. to CA in industries with } 1000< \\
\text { HHI }<1800(N=58)\end{array}$ & $\begin{array}{l}7.54 * \\
(3.66)\end{array}$ & $\begin{array}{l}14.73 * \\
(6.73)\end{array}$ & $\begin{array}{c}6.13+ \\
(3.46)\end{array}$ & $\begin{array}{l}5.62 * \\
(2.69)\end{array}$ \\
\hline $\begin{array}{l}\text { Nonutilities, subj. to CA in industries with } 500< \\
\qquad \mathrm{HHI}<1000(N=83)\end{array}$ & $\begin{array}{l}-3.06 \\
(3.18)\end{array}$ & $\begin{array}{l}-7.87 \\
(5.84)\end{array}$ & $\begin{array}{l}-3.59 \\
(3.01)\end{array}$ & $\begin{array}{l}-2.18 \\
(3.33)\end{array}$ \\
\hline Constant & $\begin{array}{c}-2.97+ \\
(1.57)\end{array}$ & $\begin{array}{l}-5.85^{*} \\
(2.88)\end{array}$ & $\begin{array}{c}-2.76+ \\
(1.48)\end{array}$ & $\begin{array}{r}-7.99 * \\
(1.15)\end{array}$ \\
\hline
\end{tabular}

OLS regression, std. errors (in parentheses) clustered at the 4-digit SIC code level. CA, Clayton Act.

*Indicates statistical significance at the $5 \%$ level.

+Indicates statistical significance at the $10 \%$ level.

as a relaxation of a regulatory regime previously hostile to horizontal mergers. Moreover, these actors perceived this relaxation immediately upon the announcement of the new guidelines and did not wait for the Department to generate additional signals about the content of enforcement policy.

To further explore our results, we conducted a number of different robustness checks. We began by examining the role that market concentration plays in the results by running an additional regression with three potential treatment groups. For all three groups, we only include firms subject to the Clayton Act, except energy utilities and telecommunications firms. The first group includes the 78 of those firms that are in industries with HHI's greater than 1800 . The second group includes the 58 of those firms that are in industries with HHI's between 1000 and 1800 (that is, the Model 3 treatment group), and the third group includes the 83 of those firms that are in industries with HHI's between 500 and 1000 . The results of this regression are presented in Table 2. Note that the coefficient for those firms in industries between 1000 and 1800 is consistently positive and significant, similar to the results for Models 3 and 4 in Table 1 . The coefficients on the other two groups are consistently negative, as is the coefficient on the constant term, although only the coefficient on the constant term is consistently significant. Thus, these results confirm our earlier results that the group of S\&P 500 firms in moderately concentrated industries experienced an increase in stock market returns after the announcement of the new Merger Guidelines while firms in more or less concentrated industries did not. This finding is consistent with investors believing that the new Guidelines did not significantly alter the prospect of merger enforcement for firms in industries with HHIs between 500 and 1000 or for firms in industries with HHIs above 1800 . 
Recall that for manufacturing industries, we used 4-digit SIC codes to define relevant markets for determining concentration levels, although due to data limitations, we used 3-digit SIC codes to define markets for nonmanufacturing industries. As another robustness check, we reran various models using concentration data for manufacturing industries derived from the same source and, in the same manner, as for nonmanufacturing industries. In particular, we assigned manufacturing industries concentration levels derived from the 3-digit SIC codes. Generally speaking, the signs on the various coefficients were the same as in the original runs. At the same time, fewer of these coefficients were significant. These results are not surprising, given that reliance on broader markets is less likely to replicate the actual antitrust markets and would therefore produce less precise results. ${ }^{98}$ As another sensitivity analysis, we added Market Valuation as a proxy for firm size and included this variable in Model 3, both on its own and interacted with the treatment dummy. The results for these regressions are provided in Table $3 .^{99}$ Neither the coefficients on Market Valuation alone nor the coefficients on the Treatment*Market Valuation interaction are ever significant. However, the coefficients on the Treatment dummy alone continue to be positive and statistically significant.

One common concern with event studies is whether one has actually identified the appropriate event around which to look for a market reaction. In particular, and as noted previously, Binder cautions that regulatory event studies pose a particular challenge because various steps in the political and regulatory process leading to regulatory change can signal the possibility and nature of potential change to capital markets. ${ }^{100}$ After studying the impact of regulatory and deregulatory announcements in different industries, Binder concludes that "it is extremely difficult to find announcements in the regulatory process that are unanticipated by the market."101 We note that this criticism suggests that the results we find here are likely to underestimate the true impact of the 1982 Guidelines. However, we nonetheless sought to investigate whether pre-1982 events could have anticipated the 1982 announcement. Thus, we examined the impact of arguably the most significant other deregulatory event, the 1981 dismissal of the facing brick suit. ${ }^{102}$ As noted in Section 3, this suit, brought in the waning days of the Carter Administration, challenged a transaction between firms of relatively modest market shares that plainly contravened the 1968 Guidelines. It is possible that Baxter's public and widely reported dismissal of a case brought so recently by the preceding Administration signaled that enforcement policy

98 Results available from the authors upon request.

99 Due to missing data on shares outstanding, there is one fewer observation in this regression.

The omitted firm is an energy utility and would have been in the control group.

100 See John J. Binder, Measuring the Effects of Deregulation with Stock Price Data, 16 RAND J. ECON. 167 (1985).

101 See id. at 181.

102 See n. 60, supra and accompanying text (discussing Baxter's decision to dismiss this case). 
Table 3. Sensitivity analysis for market valuation

\begin{tabular}{|c|c|c|c|c|}
\hline $\begin{array}{l}\text { Estimation window } \\
\text { Event window } \\
\text { Estimation price index }\end{array}$ & $\begin{array}{l}\text { EST30 } \\
\text { EV5 } \\
\text { Wilshire } \\
5000\end{array}$ & $\begin{array}{l}\text { EST30 } \\
\text { EV9 } \\
\text { Wilshire } \\
5000\end{array}$ & $\begin{array}{l}\text { EST300 } \\
\text { EV5 } \\
\text { Wilshire } \\
5000\end{array}$ & $\begin{array}{l}\text { EST30 } \\
\text { EV5 } \\
\text { S\&P } \\
500\end{array}$ \\
\hline $\begin{array}{l}\text { Treatment: nonutilities, subj. to CA, } 1000< \\
\qquad \text { HHI }<1800(\mathrm{~N}=58)\end{array}$ & $\begin{array}{l}10.47^{*} \\
(4.36)\end{array}$ & $\begin{array}{l}20.40^{*} \\
(8.01)\end{array}$ & $\begin{array}{l}10.57^{*} \\
(4.12)\end{array}$ & $\begin{array}{c}9.69 * \\
(3.19)\end{array}$ \\
\hline Market valuation (\$million) & $\begin{array}{c}0.16 \\
(0.35)\end{array}$ & $\begin{array}{c}0.34 \\
(0.64)\end{array}$ & $\begin{array}{c}0.23 \\
(0.33)\end{array}$ & $\begin{array}{c}0.02 \\
(0.26)\end{array}$ \\
\hline Treatment $\times$ market valuation ( $\$$ million) & $\begin{array}{l}-1.20 \\
(1.59)\end{array}$ & $\begin{array}{l}-1.84 \\
(2.93)\end{array}$ & $\begin{array}{l}-1.72 \\
(1.50)\end{array}$ & $\begin{array}{l}-1.81 \\
(1.17)\end{array}$ \\
\hline Constant & $\begin{array}{r}-4.53^{*} \\
(1.36)\end{array}$ & $\begin{array}{r}-9.12^{*} \\
(2.50)\end{array}$ & $\begin{array}{l}-4.81^{*} \\
(1.29)\end{array}$ & $\begin{array}{c}-9.21^{*} \\
(1.00)\end{array}$ \\
\hline
\end{tabular}

OLS regression, std. errors (in parentheses) clustered at the 4-digit SIC code level. CA, Clayton Act.

*Indicates statistical significance at the $5 \%$ level.

+ Indicates statistical significance at the $10 \%$ level.

had changed in a significant fashion. We tested this possibility by rerunning our various models with estimation and event windows built around the date the Department announced it was dismissing this suit. We found no significant effects on any model's treatment group. ${ }^{103}$ This result suggests that this announcement had a substantially smaller impact upon the regulatory expectations of market participants than the announcement of the new Guidelines. Additionally, we ran two falsification tests for randomly selected dates 50-100 days before and after the announcement and found no statistically significant effects for any of the treatment groups. If some other factor (such as a "takeover premium") unrelated to the announcement of the new Guidelines made firms in industries with HHIs between 1000 and 1800 uniquely attractive to investors, we would expect to observe similar results for the randomly selected days which we do not.

We also scrutinized the event window for other developments that could somehow account for the results we obtained. A review of the "What's News" section of the Wall Street Journal (WSJ) on the event date as well as two business days before and after the date revealed no events that seemed likely to uniquely affect the moderately concentrated industries in the Model 3 treatment group. However, this review of events did identify the June 14 ceasefire in the Falkland Islands War and formal surrender of Argentine forces on the same day (just over three weeks after British troops landed on the islands) as a possible confounding event. Major newspapers, including the WSJ, reported the surrender and ceasefire on June 15, although some market actors apparently received the news on the afternoon of June $14 .{ }^{104}$ However, the S\&P 500 fell

${ }^{103}$ Results available from authors upon request.

${ }^{104}$ A WSJ article on June 15, 1982 reported that "the [June 14] slide continued despite late reports of a cease-fire in the Falkland Islands." See Victor J. Hillery, Broad Decline in Slow 
0.25 percent on June 15, the first full trading day after announcement of the ceasefire, and WSJ's June 16th account of the previous day's market activity did not mention the Falklands War. In any event, the end of the Fallklands War could only account for our results if that event's effect on the treatment group differed from its effect on the control group. Any market-wide effect of the ceasefire announcement (or any other event) would be captured in the coefficient on the model's constant term. Moreover, only a differential positive effect upon stocks in the treatment group would constitute an alternative explanation for our results, as a negative effect would indicate that our results were an underestimate of the impact of the announcement of the 1982 Guidelines on the treatment group.

A review of media reports leading up to the May 21 British landings on the Falklands suggested that market actors believed that a prolonged military conflict would negatively affect the economy of the United Kingdom, a major U.S trading partner, by weakening the British pound and causing higher interest rates, inducing a tax increase to pay for military operations and/or destabilizing the Thatcher government. ${ }^{105}$ The ceasefire following a rapid British victory presumably moderated these concerns, brightening prospects for the United Kingdom's economy. A stronger British economy would, in turn, increase U.S. exports to the UK and expected profits of exporting firms. Even if one assumes that firms in the Model 3 treatment group were particularly reliant on exports to the United Kingdom, any plausible estimate of the ceasefire's impact would be minuscule compared with the positive abnormal returns we observed. ${ }^{106}$

We also considered the possibility that the cessation of the Falklands War could have impacted not only trade with the UK, but also international trade more globally. Once again, for this to explain the positive coefficient we find on the treatment group dummy, the improvement in prospects for international trade had to affect our treatment group differentially. To assess the likelihood of this possibility, we conducted three additional analyses. First, we sought to examine the relative import intensity of industries represented in our control and treatment groups based on the expectation that domestic firms in import-heavy industries would benefit from disturbances that disrupt global trade and thus would experience reduced returns upon the elimination of such disturbances. Using data from 1982 to 1987 , one scholar identifies

Trading Day Is Triggered by Interest Rate Fears, WALL STREeT JournaL, June 15, 1982, at p. 55.

105 See David Brand, British Economy Could Be Victim If a War Begins, WaLl STREeT JournaL, April 21, 1982, at 33.

106 U.S. exports to the UK totaled about $\$ 10.6$ billion in 1982 , while U.S. GNP was just over $\$ 3$ trillion. See U.S. Bureau of The Census, Statistical Abstract of The United STATES, 845 (1984) (export figures); id. at 448 (GNP figures). Thus UK exports accounted for less than four tenths of one percent of US GNP in 1982. Even a ten percent increase in such exports would increase US GNP by less than four one-hundredths of one percent. 
import-sensitive manufacturing industries at the 4-digit SIC code level. ${ }^{107}$ Using this information, we first assessed whether there was a statistically significant difference in the percentage of manufacturing firms in the treatment group and control groups that were import-sensitive and found that the difference was not statistically significant at conventional levels, although the percentage was slightly lower for the treatment group (12.2\% compared with $12.7 \%$ ). Next, we reran Model 3 for manufacturing firms only, with a dummy variable for firms in import-sensitive industries. ${ }^{108}$ As shown in Table 4, although the coefficient on Import-Intensive Industry has the expected negative sign, it is not significant for any of the four parameter sets. More importantly for our analysis, the coefficient on the treatment dummy continues to be positive and significant for all four parameter sets. Thus, we continue to observe moderately concentrated firms in industries subject to the Clayton Act exhibiting a positive cumulative abnormal return during the event window surrounding the announcement of the 1982 Guidelines. ${ }^{109}$

We next examined relative export intensity under the expectation that any increased difficulty in trading will differentially impact those firms that derive a significant percentage of sales from exports, with the result that reversal of such events will differentially increase the expected profits of such firms. We again used data on export intensity for 4-digit manufacturing firms from 1982 to 1987 and, as was the case with import sensitivity, the percentage of Model 3 treatment firms in export-sensitive manufacturing industries is not statistically significantly different from the percentage of control firms, although in absolute terms, there are more export-sensitive firms in the treatment group than in the control group ( $21.2 \%$ vs. $14.5 \%$, respectively). ${ }^{110}$ As we did in the import analysis, we reran Model 3 for manufacturing firms only with a dummy variable for firms in export-sensitive industries. As shown in Table 4, the coefficient on export-intensive industry is negative and significant. Although this is not consistent with our expectations, note that the coefficient on the treatment dummy continues to be positive and significant

107 See Robert W. Bedzarnik, An Analysis of U.S. Industries Sensitive to Foreign Trade, 1982-1987, 116 Monthly LAB. REv. 15 (1993). Bednarzik only considers manufacturing industries. He defines import-intensive industries as those with an average import-penetration of 30 percent or more. Although many nonmanufacturing industries also export (agriculture, mining, etc.) many do not (utilities, services industries, etc.).

108 Although only 60 percent of the whole sample are manufacturing firms (287 firms), the Model 3 results for the manufacturing only firms are very similar to the results for all 477 firms.

109 We repeated this analysis using data on 1972-1979 import sensitivity from a previous analysis. See Gregory K. Schoepfle, Imports and Domestic Employment: Identifying Affected Industries, 105 MONTHLY LAB. REV. 13 (1982). The results were qualitatively the same-that is, the coefficient on Import-Intensive Industry was not significant, although the coefficient on the treatment dummy was positive and significant.

110 See Bedzarnik, Analysis of U.S. Industries Sensitive to Foreign Trade, 1982-1987, 116 MonTHLY LAB. REV. at 16 (defining as "export intensive" those industries with an average export-penetration of 20 percent or more). 
Table 4. Analyses of import/export sensitivity and global exposure

\begin{tabular}{lllll}
\hline Estimation window & EST30 & EST30 & EST300 & EST30 \\
Event window & EV5 & EV9 & EV5 & EV5 \\
Estimation price index & Wilshire & Wilshire & Wilshire & S\&P \\
& 5000 & 5000 & 5000 & 500 \\
\hline
\end{tabular}

\begin{tabular}{lcccc} 
Manufacturing firms only $(\mathbf{N}=\mathbf{2 8 7})$ : import-intensive analysis & & \\
Nonutilities, subj. to CA in industries with & $8.89^{*}$ & $16.02^{*}$ & $8.41^{*}$ & $8.17^{*}$ \\
$1000<\mathrm{HHI}<1800(N=33)$ & $(3.28)$ & $(5.84)$ & $(3.53)$ & $(3.10)$ \\
In import-intensive industry $(N=87)$ & -3.73 & -6.87 & -2.32 & -3.73 \\
& $(3.28)$ & $(5.84)$ & $(3.53)$ & $(3.10)$ \\
Constant & $-4.11^{*}$ & $-7.65^{*}$ & $-4.88^{*}$ & $-8.99^{*}$ \\
& $(1.15)$ & $(2.06)$ & $(1.24)$ & $(1.09)$ \\
Manufacturing firms only $(N=287)$ : export intensive analysis & & \\
Nonutilities, subj. to CA in industries with & $9.28^{*}$ & $16.66^{*}$ & $9.15^{*}$ & $8.71^{*}$ \\
$1000<\mathrm{HHI}<1800(N=33)$ & $(3.22)$ & $(5.73)$ & $(3.43)$ & $(3.01)$ \\
In export-intensive industry $(N=87)$ & $-9.83^{*}$ & $-17.04^{*}$ & $-12.05^{*}$ & $-11.56^{*}$ \\
& $(2.96)$ & $(5.28)$ & $(3.16)$ & $(2.77)$ \\
Constant & $-3.22^{*}$ & $-6.14^{*}$ & $-3.55^{*}$ & $-7.87^{*}$ \\
& $(1.15)$ & $(2.06)$ & $(1.23)$ & $(1.08)$ \\
All firms $(N=477):$ global exposure analysis & & & & \\
Nonutilities, subj. to CA in industries with & $8.77^{*}$ & $17.30^{*}$ & $7.82^{*}$ & $6.80^{*}$ \\
1000< HHI < 1800 $(N=58)$ & $(3.52)$ & $(6.50)$ & $(3.34)$ & $(2.60)$ \\
In globally exposed industry $(\mathrm{N}=197)$ & -1.21 & -3.15 & 0.67 & 0.45 \\
& $(2.35)$ & $(4.31)$ & $(2.22)$ & $(1.72)$ \\
Constant & $-3.74^{*}$ & $-7.22^{*}$ & $-4.70^{*}$ & $-9.34^{*}$ \\
& $(1.57)$ & $(2.89)$ & $(1.49)$ & $(1.15)$ \\
\hline
\end{tabular}

OLS regression, std. errors (in parentheses) clustered at the 4-digit SIC code level. CA, Clayton Act.

*Indicates statistical significance at the $5 \%$ level.

+Indicates statistical significance at the $10 \%$ level.

for all four parameter sets. Thus, although firms in export-intensive industries did see lower CARs than firms in import-intensive industries, there continues to be evidence of increased stock prices at firms most likely to benefit from the 1982 Merger Guidelines.

Of course, although import and export intensity make sense as proxies for exposure to world events for manufacturing facilities, they do not for many other facilities in our study. Thus, we also use Grinold, Rudd and Stefek's measure of global exposure of industries based on data from 1983 to 1988 to determine whether more globally exposed firms were differentially affected by the ceasefire. ${ }^{111}$ In this context, global exposure measures the dependence of security prices on global events relative to domestic events. ${ }^{112}$ As was the case

111 See Richard Grinold, Andrew Rudd, \& Dan Stefek, Global Factors: Fact or Fiction, $16 \mathrm{~J}$. PORTFOLIO MGMT. 79 (1989).

${ }^{112}$ More specifically, Grinold, Rudd and Stefek identify industries as globally exposed if security prices in the industry behave similarly across all countries. See id. Industries that react to domestic events and thus have significant variation across countries are considered to be less exposed. As was the case for import and export-intensity, we use a threshold value to create 
Table 5. Sensitivity analysis for oil industry

\begin{tabular}{|c|c|c|c|c|}
\hline $\begin{array}{l}\text { Estimation window } \\
\text { Event window } \\
\text { Estimation price index }\end{array}$ & $\begin{array}{l}\text { EST30 } \\
\text { EV5 } \\
\text { Wilshire } \\
5000\end{array}$ & $\begin{array}{l}\text { EST30 } \\
\text { EV9 } \\
\text { Wilshire } \\
5000\end{array}$ & $\begin{array}{l}\text { EST300 } \\
\text { EV5 } \\
\text { Wilshire } \\
\text { 5000 }\end{array}$ & $\begin{array}{l}\text { EST30 } \\
\text { EV5 } \\
\text { S\&P } \\
500\end{array}$ \\
\hline $\begin{array}{l}\text { Nonutilities, subj. to CA, } 1000<\mathrm{HHI}< \\
\qquad 1800(N=58)\end{array}$ & $\begin{array}{l}7.43 * \\
(3.58)\end{array}$ & $\begin{array}{l}14.77^{*} \\
(6.58)\end{array}$ & $\begin{array}{c}6.33+ \\
(3.39)\end{array}$ & $\begin{array}{l}5.58^{*} \\
(2.62)\end{array}$ \\
\hline In oil industry $(N=19)$ & $\begin{array}{l}12.41 * \\
(5.99)\end{array}$ & $\begin{array}{l}23.62^{*} \\
(11.00)\end{array}$ & $\begin{array}{l}13.13^{*} \\
(5.68)\end{array}$ & $\begin{array}{l}10.76^{*} \\
(4.39)\end{array}$ \\
\hline Constant & $\begin{array}{c}-4.57^{*} \\
(1.24)\end{array}$ & $\begin{array}{c}-9.15^{*} \\
(2.27)\end{array}$ & $\begin{array}{c}-4.77^{*} \\
(1.17)\end{array}$ & $\begin{array}{r}-9.43 * \\
(0.91)\end{array}$ \\
\hline
\end{tabular}

OLS regression, std. errors (in parentheses) clustered at the 4-digit SIC code level. CA, Clayton Act.

*Indicates statistical significance at the $5 \%$ level.

+Indicates statistical significance at the $10 \%$ level.

for import and export sensitivity, the percentage of globally exposed firms did not differ statistically between the Model 3 treatment and control groups (58.6-61.7 percent, respectively). Also, as shown in Table 4, when a dummy for global exposure was included in the regressions of cumulative abnormal returns during the event window, the resulting coefficient was not statistically significant, although the coefficient on the treatment dummy remained positive and significant. Here again, there is no evidence that differences in global exposure caused a differential response to the Fallzlands ceasefire or accounted for the increased CAR for firms in the Model 3 treatment group.

Our review of economic events during this period also revealed that oil prices and retail gasoline prices rose significantly between the end of the estimation period, April 30, 1982, and the event window in June of 1982. Additionally, spot oil prices rose during the event window itself. Thus, as shown in Table 5, we added a dummy variable, Oil, to the Model 3 regression. Of the 19 oil firms (that is, firms in either SIC 1311 -Crude Petroleum and Natural Gas Extraction or SIC 2911-Petroleum Refining) in our sample, all 19 are in the treatment group for Model 3. Thus, we do not include an interaction between Oil and the treatment group. Note that for all parameter sets, the coefficient on Oil is positive and significant indicating that firms involved in petroleum extraction and refining have a significantly higher CAR than other firms. However, the positive and significant coefficients on the treatment dummy remain for all four parameter sets, reconfirming our finding that the announcement of the 1982 Merger Guidelines resulted in a positive increase in firm value for firms with HHIs between 1,000 and 1,800 that were subject to Clayton Act regulation during this period.

a dummy variable indicating high global exposure. We define globally exposed industries to be those where the "industry factor" is significant in determining security prices over $60 \%$ of the time. 


\section{CONCLUSIONS}

Nonbinding guidelines are regularly issued by a number of executive agencies. This paper examines whether such guidelines can have a real effect on market perceptions of agency policy. In particular, we study the impact of the 1982 Department of Justice Merger Guidelines, which announced a substantial departure from the merger enforcement policy contained in the 1968 Guidelines they replaced. Although the 1982 Merger Guidelines articulated a substantially less intrusive enforcement policy, the promulgation of nonbinding enforcement guidelines may not have resulted in a meaningful change in actual enforcement policy. Indeed, some contend that change in enforcement policy is necessarily gradual and that the Department's enforcement policy had already departed significantly from the 1968 Guidelines well before the Department announced the 1982 Guidelines. Others, however, assert that the new Guidelines signaled a substantial and abrupt change in policy. Our analysis sought to determine empirically whether market actors perceived the 1982 announcement as a harbinger of substantial change.

Using an event-study of the stock prices of S\&P 500 firms, we find evidence of a significant positive effect on stock prices of a particular subset of S\&P 500 firms in the days surrounding the announcement of the 1982 Guidelines, namely, firms subject to the Clayton Act that are in moderately concentrated industries (that is, have HHIs between 1000 and 1800). We argue that this group of firms corresponds roughly to the group of firms for which the new Guidelines announced a substantially more lenient enforcement policy. By contrast, the Guidelines do not appear to have effected any real change in market perceptions of enforcement policy for firms in either less concentrated or more concentrated industries. This is consistent with a per-1982 merger policy that had evolved so as not to require challenges of mergers in less concentrated markets (that is, with HHIs below 1,000). Similarly, although the 1982 Guidelines were significantly less intrusive than their 1968 predecessors, they do not appear to have convinced the market that the prior enforcement regime's hostility to transactions in markets with HHIs exceeding 1800 had changed.

These results are quite robust to a wide range of sensitivity analyses. Adding other explanatory variables such as market valuation and indicators for input and export sensitivity, global exposure, and oil firms do not alter these findings. The results are also robust to different estimate and event windows and different predictors of market returns. Finally, when we examine other event windows both for arguably relevant dates and for random dates, we do not find a similar effect. Thus, we believe that these findings clearly point to the 1982 Merger Guidelines as signaling a credible change in U.S. merger enforcement policy. 